\title{
The Role of Tawheedic Stimulus in the Conscience of Muslim Individuals
}

\author{
Abdi 0. Shuriye \\ Department of Science Faculty of Engineering, International Islamic University Jalan Gombak 53100 Malaysia
}

Email: shuriye@iium.edu.my

Doi:10.5901/mjss.2014.v5n23p1940

\section{Abstract}

Muslim individual's worldview, culture and ethics are based on tawheed. In social, political and religious contexts, emotional state and motivational status of these individuals also inject perceptional premise to the way these individuals set value related priorities. The way Muslims see things, are mainly derived from faith, experience and family background. Values, knowledge and religious consciousness are therefore, the essence of tawheed in the mind of modern Muslim individuals. The key objective of this paper is to assess how these values are perceived by Muslim individuals in relation to the current world affairs and human relation within the socio-political and diverse worldviews. Muslim normative epistemological attitude towards tawheedic ethos in relation to the current reality of the technological and scientific development must be reassessed for further contextualization. Islam advocates good reasoning and tawheed has to be comprehended within the cognitive apparatus of the modern Muslim individual.

Keywords: tawheed, faith, Muslim individuals, worldview, ethics, religion.

\section{Introduction}

Tawheed, (Oneness of God) and 'aqidah (belief) in Islam refer simultaneously to the link between the individual and Allah; a complete submission to the will of God. However this depends on the religion one adheres to, the believer and the nature of the belief system itself. Muslims see tawheed as an element of life in its totality, while Christians may confine it to the church. At the same time, informal usage of faith can be quite broad, including trust and belief without proof. In effect, in some occasions, faith is used as a substitute for hope or trust. Outside the Islamic society, some still may deem that faith is opposed to reason, while others may compromise and contend that, the proper domain of faith concerns questions which cannot be settled by evidence. This paper uses survey as its main method to examine the aforementioned issues. Surveys are key instrument in collecting random data through selected samples. The respondents for this survey consist of IIUM population.

The study, in its complete form, investigates the impact of tawheed on Muslim individuals in their attitude, behavior, and in their consciousness in diverse aspects of life. A total of 84 participants were involved in the survey. The respondents of this study consisted of $49 \%$ male Muslims, and $35 \%$ female Muslims. The questionnaires were divided into five sections. Section one, covered the tawheedic motivation or stimuli on Muslim life, on work, on professionalism and on God consciousness (taqwa). Section two of the questionnaire run on the sense of right and wrong in Islam, the influence of tawheed in avoiding sinful activities, and the role of faith, experience, and family background on Muslim way of thinking. The third section covered education and epistemic values and the role of tawheed in seeking knowledge, understanding religious sciences and the process of learning in Islam. Whereby, section four covered modernity, culture, customs and ethnicity as well as nationalism and the position of tawheedic stimuli on the aforementioned. Section five meanwhile, studies the impact of tawheed on human values, identity, ethical values, religious values, and personality development. This paper studies the first two sections of the research based on the survey. Table 1.1 below illustrates the distribution of questionnaires according to gender.

Table 1.1: Respondent's Demographic Characteristics

Frequency and Percentages of the Demographic Characteristics of the Respondents

\begin{tabular}{ccc}
\hline Characteristics & Frequency $(\mathrm{n})$ & Percentage $(\%)$ \\
\hline Gender & & \\
Male & 49 & 58.3 \\
Female & 35 & 41.7 \\
Total & 84 & 100 \\
\hline
\end{tabular}

$(n=84)$ 


\section{Tawheedic Stimulus as a Source of Motivation and Success}

Based on the responses given, participants are aware, with surety, that tawheedic stimulus is a source of motivation and success in life. In the survey more that $97.6 \%$ of the respondents have agreed on the item that "my belief in God supports me to succeed in my life", whereby only $2.4 \%$ have disagreed with the statement. With this, it is obvious that participants understand the relationship between tawheed and life and through having strong faith in God one can succeed in the worldly life and be a better person. The spirit and the soul of Islam could not stand without tawheed. For tawheed is the backbone of the structure and the house. Faruqu, in addressing this fact, contends "The essence of Islam is tawheed... and obviously, no commandment in Islam would hold without tawheed. The whole religion itself, man's obligation to serve God, to fulfill His commandments and to observe his prohibition would fall on the ground the moment tawheed is violated". (Ismail Raji Al Faruqi, 1995)

The tawheedic stimulus is the centre of encouragement to discover, develop and expand one's worldview and knowledge and these are the traits of civilization and social development. In actual fact, having faith in Allah gives the person a form of certainty and confidence. Besides, tawheed has a great deal of things to offer to Muslim individuals in the sense that it provides purpose of life, structure and guidelines as it covers the whole culture, civilization and history of Muslim individuals. Put differently, In Islam without faith reason errors and misleads life to whims. Afif on this asserts, "In fact, of all religions, Islam alone uses reason in matters of devotion, especially in giving evidence of the existence of the creator". (Afif A. Tabbarah, 1988) Faruqi further illustrates that, "Traditionally and simply expressed, tawheed is the conviction and witnessing that, there is no god but God. This seemingly negative statement, brief to the utmost limits of brevity, carries the greatest and richest meanings in the whole Islam. Sometimes a whole culture, a whole civilization or a whole history lies compressed in one sentence. This certainly is the case of the kalimah or shahadah of Islam". (Ismail Raji Al-Faruqi, 1995)

If truth be told, tawheedic worldview endows with Muslim individuals the accurate interpretation of the content of the universe; hence, it is the presupposition that influences one's outlook on life. In the case of Islam particularly, personal insights on the notions such existence or nonexistence, the origins of the universe and of human life; the source of morality and values and identification of what is good or evil or how to live one's life and the meaning of life and death are the crux of tawheedic paradigms. Table 2.1 below elucidates the outcome of the survey.

Table 2.1: Frequency and Percentage on belief in God supports me to succeed in my life

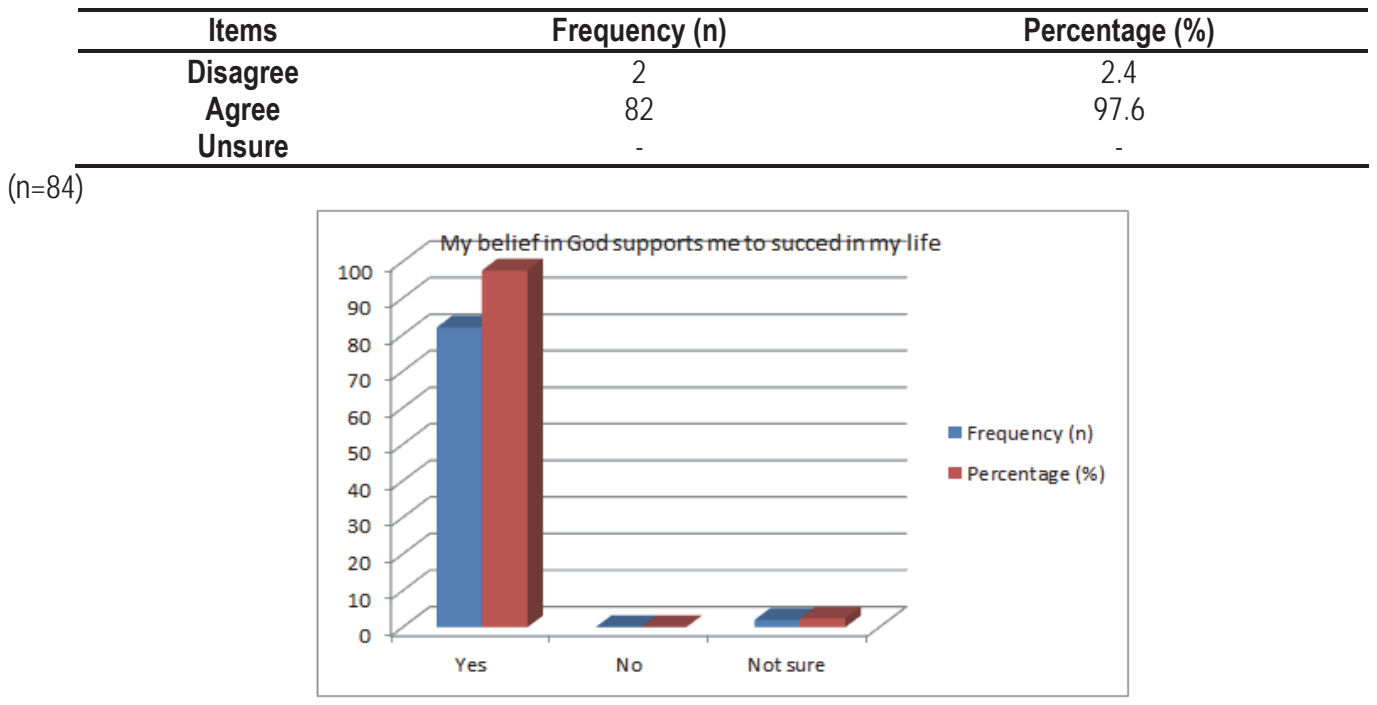

On the question that "Taqwa is not only the motivating factor for me to work harder", about $10.7 \%$ of the participants agreed on this item, while $19.0 \%$ of them are unsure and about (10.7\%) of them have disagreed. This is a clear indication that modern Muslim individuals have no accurate understanding on the relationship between taqwa, which is the core principle of tawheed, and working hard to achieve high in life. The teachings of Islam placed great emphasis on working hard to achieve blessings in here and hereafter. The Qur'an made it clear the importance of observing time and that it should not be wasted. The Qur'an also tells us how Allah has created the universe within certain period of time as a sign 
for man to emulate and learn from the Creator to complete tasks within the stipulated space of time. In surah an-Najm we read the Qur'anic dictum in which Allah explains how man should work hard to make use of His bounty on earth for his benefit and that man achieves nothing but what he strived for. Allah says: "That man can have nothing but what he strives for; that (the fruit of) his striving will soon come in sight: then will he be rewarded with a reward complete". (An-Najm verse 39)

Indeed, any work performed by a Muslim is considered as an act of worship and the right conception of worship is not to stay in the mosque rather to seek the bounty of Allah (Fadhl Allah) to be stronger Muslim and have the upper hand (al-yad al-'ulya) in all aspects of life. The Qur'an on this reads: "And when the prayer has been concluded, disperse within the land and seek from the bounty of Allah, and remember Allah often that you may succeed." (Surah al-Jun'ah verse 11)

A Muslim individual without taqwa has no consciousness of God. The closest English words to taqwa are forbearance and abstinence. Without da'wah, taqwa may not be achieved. Syed Asad agrees, "In the sight of Allah, the most excelled and the highest work for this world and the hereafter and for the benefit and progress of mankind is to call other creatures of Allah toward obedience and worship of their creator. That is why it is necessary that people of the best capacities should adopt this work and however, busy they might be in their worldly pursuits, should take up their share into this great work in order to fulfill the trust placed in them by Allah" (Syed Asad Gilani, 1982)

More to the point, taqwa is the state of high spirituality, purity of heart and soul and strong link between the individual and Allah. Keeping Allah's presence in one's conscious motivates the individual to carry out virtuous and upright deeds and avoid vice and forbidden activities. Afif reminds, "That is why the Qur'an brought forth a divine law based on faith in God, to exalt man's sprit, make him a good member in the human community and save him from the crashing tortures of the mental crises he might undergo due to his ignorance of the secrets of the universe. The Qur'an calls on man to train his sprit by doing good, and to clean his heart from the filth of desires, hatred and envy, so that people may meet on amity and peace" (Afif A. Tabbarah, 1988)

The fundamental function of taqwa is to shield and guard the individual against the anger of Allah (Sakhad Allah). In surah ala Imran the Almighty Allah states that: "O you who believe! Have taqwa of Allah, as you should have of Him and do not die except as Muslims." (Surah ala Imran verse 102) Table 2.2 explains the frequency and the percentage of the survey on "taqwa is not only motivating factor for me to work harder".

Table 2.2: Frequency and Percentage on taqwa is not only motivating factor for me to work harder

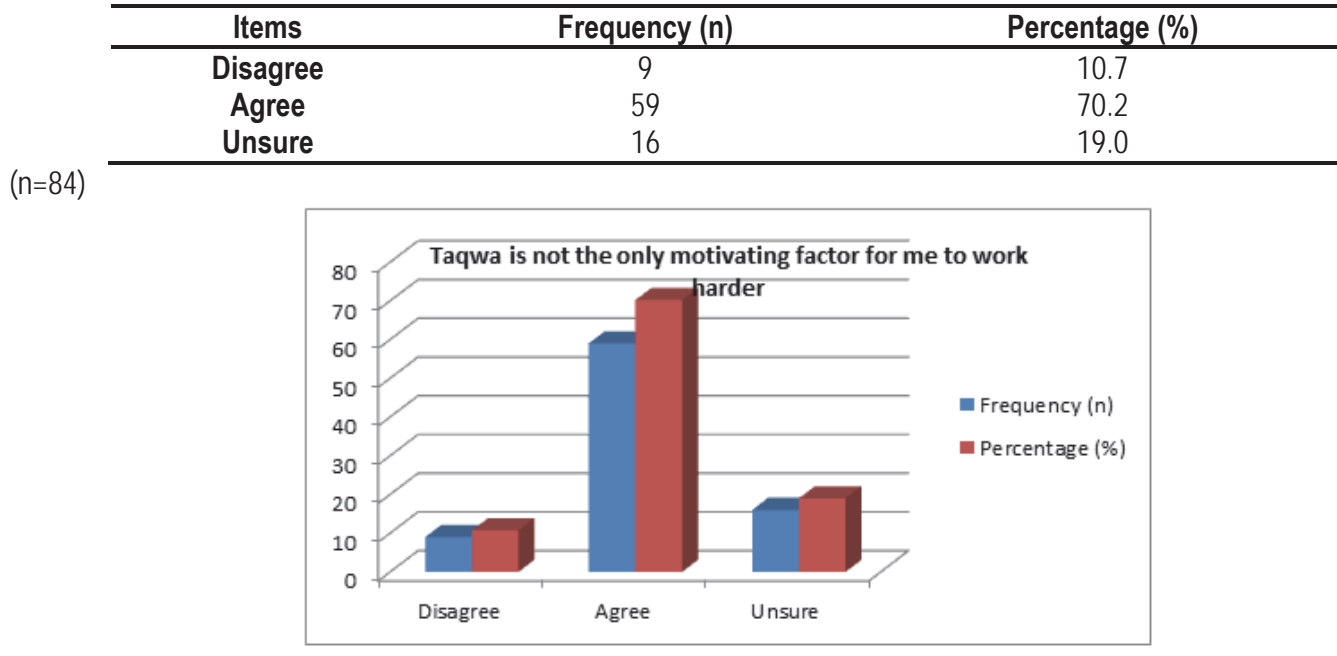

Another related issue surveyed under this section is the item that "to be a good professional, I need to have a religion". In this item $100 \%$ of the respondents have agreed to it. Professionalism is to do things in a perfect manner and one needs tawheedic stimulus to accomplish real perfectionism in management, production, positive attitude, superior behavior as well as to design beneficial materials for the society. This is what the respondents on this item have agreed to.

In conventional terms, professionalism means professing loud of one's knowledge with skills and confidence. In its early use, the term was associated with vow made on entering a religious order. (Charles E Harris et al, 1995) Professionalism also refers to a person with monastic vows; a person who had made public promises to enter a distinct way of life with high moral standards. (Abdi O. Shuriye, 2006) Hence, professionalism has its origin in tawheed and 
ethics; the two main motivating elements for a Muslim individual to perform righteous deeds and avoid the outlawed. With this in mind, performance is maximized through istiqamah (perpendicular-conscious), thoroughness and competence.

A professional Muslim must aim to be a mutqin, that is to say, he does his best in whatever he performs. Itqan or striving to achieve distinction and ihsan or doing things with God's consciousness are the core of professionalism in Islam and they both emanate from tawheed.

Ihsan in Islam is the highest level of tawheed as it gives the surety that Allah is watching over man in any task he perfumes. This is in line with the fact that, the crux of Islamic faith is to observe high level of righteousness, perfectionism, and doing and saying the ultimate good. For Muslim individuals the ultimate good is to do what God commanded them or, in other words, to do or say things that are in line with the ethos of the Shariah. In the Hadith of the Prophet Ihsan is defined as: "To worship Allah as if you see Him, and if you do not see Him, He sees you." This is the highest status of tawheed as it covers all the activities of Muslim life. The English word worship is not synonymous with ibadah in Islam as 'ibadah refers to all actions which a Muslim individual performs in his daily routine. Therefore with insan, Muslim individuals are under constant state of God's consciousness.

This account is in sequence with the Qur'anic verse on ihsan in which Allah says: "Nay, whoever submits his whole self to Allah and is a doer of (Ihsan) good he will get his reward with his Lord; on such shall be no fear, nor shall they grieve." (Al-Baqarah verse 112). The Qur'anic message in its totality advocates ihsan and it has more than 66 verses mentioning the subject. All these verses refer to insan as an excellence in work, and excellence in social interaction. Ihsan also means to help others and provide support for the needy. The ibadah of a Muslim and his taqwa are both embodiment of insan.

Itqan on the other hand, is a term employed to signify the level of quality work. It embodies the meaning of dispose and set out things in a systematic and methodical way. The ultimate goal of itgan is to obtain perfect results in everything one performs. A related Arabic expression is inkam which denotes to act with wisdom. Itqan therefore, is about precision and completeness as the Qur'an teaches, "And you see the mountains, thinking them rigid, while they will pass as the passing of clouds. [It is] the work of Allah, who perfected all things. Indeed, He is acquainted with that which you do." Surah an-naml verse 88) the prophetic Hadith reminds, "Allah loves when you perform a deed to execute it with excellence". (Bukhari and Muslim) Itqan in this sense prescribes the idea of striving or to achieve excellence and it has the intensity to motivate Muslim professionals to perform righteous deeds and avoid workplace related illicit practices. (Abdi O. Shuriye, 2006)

On the whole, in the teachings of Islam the idea of itqan reinforces and enhances quality in running organizations, management, supervision, and plays a major role in continues improvement of performance in any related function, task or activity. Without teamwork however, and cohesion among staff itqan will remain out of reach. Allah the Almighty encourages Muslim individuals to achieve excellence in one's work. The Qur'an on this reads: "It is the nature of Allah to perfect everything" (Surah an-Naml, verse 38). Table 2.3 illustrates the frequency and percentage obtained by the survey on the statement "to be a good professional, I need to have religion".

Table 2.3: Frequency and Percentage on to be a good professional, I need to have religion

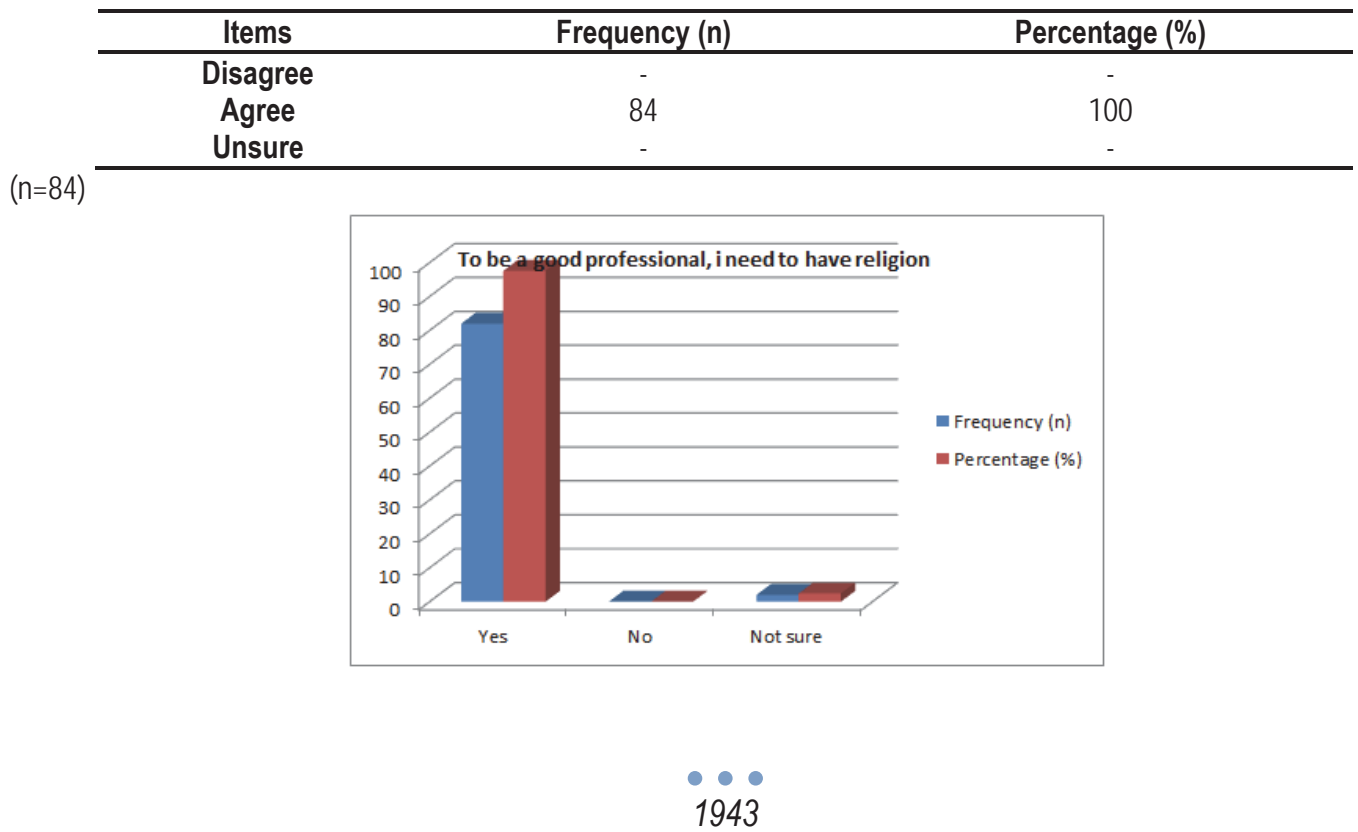




\section{The Influence of Tawheed on Muslim Individuals and the Role of Ethical Principles}

On the first question under this section the survey represents the item that "Tawheed influences me to avoid sinful activities". It is remarkable to observe that $96.4 \%$ of the participants have agreed on the item and only $3.6 \%$ of the correspondents are unsure. This item focuses on the influence of tawheed on Muslim individuals in avoiding sinful activities. What is agreed upon by the respondents is the fact that, tawheed is a natural phenomenon and it exists in the heart and mind of every Muslim individual. It comprises of feelings, sensory and natural intuition. In this aspect, tawheed refers to at-tasdiq, (believe in heart) al-iqrar, (declaring by speech) and al-'amal, (proving action). All the three meanings complete and perfect one other and with tasdiq alone a Muslim remains in the minimum level of imam; but within the domain of tawheed.

It must be understood that, in social context, tawheed significantly interacts with social values such as truth, good and right. At the same time, these values connect attributes, attitudes and the behavior of the individual; as it involves cognizance, consciousness, knowledge, virtuous, and opinion. Both in conventional and in religious terms attitudes are affective or reflective of the heart likes and dislikes. Certainly, tawheed therefore influences life as it defines the ideals of Muslim life, which are reflected in the values and attitudes of the society as a whole.

Just to elucidate the influence of tawheed on Muslim attitude, behavior and values, it is remarkable to jog our memory on the role Muslims in building advanced civilizations from $7^{\text {th }}-15^{\text {th }}$ centuries. It was the tawheedic value which has shaped the behavior and practices of Muslim individuals of early Islamic civilization. Subsequently, Tawheedic stimulus is a vital element in the development of Muslim behavior toward nature, fellow human beings, work and universe. Our understanding and appreciation of the cosmos is enriched by the tawheedic stimulus as it links our physical world with the metaphysical world. The table below simplifies the frequency and percentage attained through the survey on the item: "Tawheed influences me to avoid sinful activities"

Table 3.1: Frequency and Percentage on Tawheed influences me to avoid sinful activities

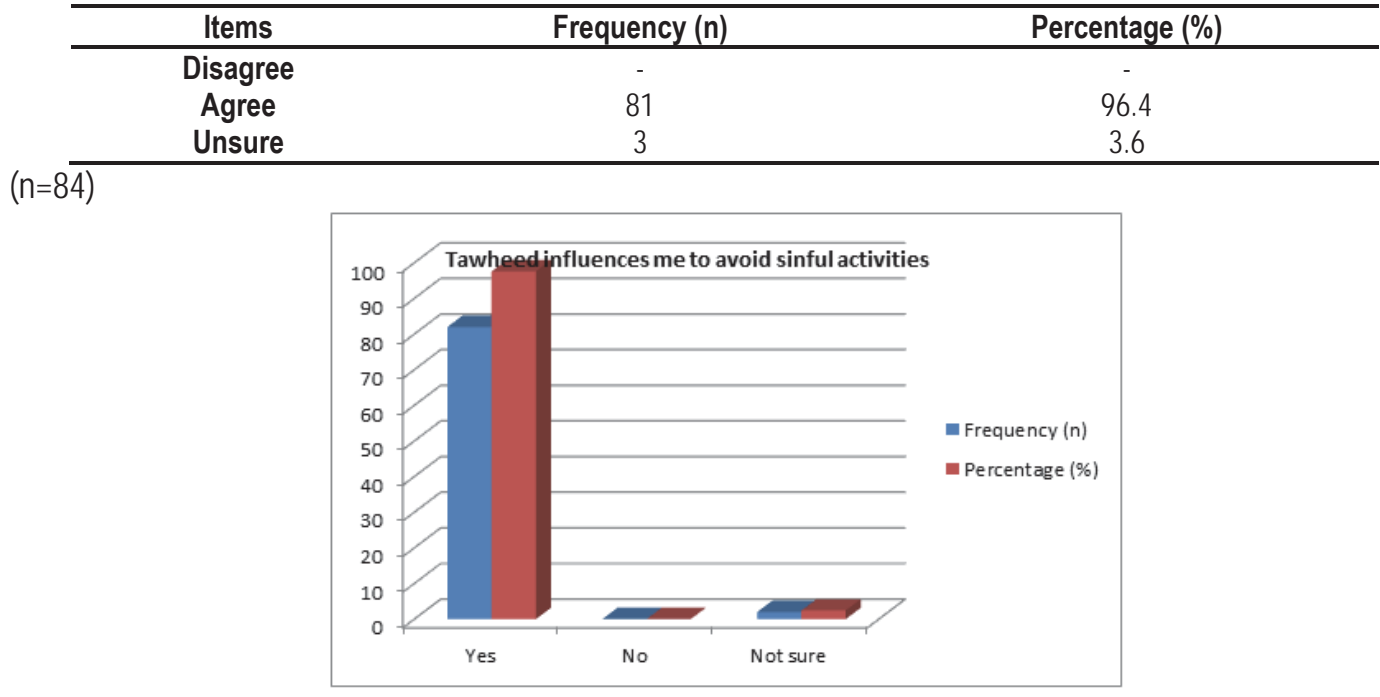

On the contention that "how I see things in life are based on my faith, experience or family background" it is remarkably motivating to note that $50.0 \%$ of the participants have agreed that how they see things in life are based on their faith. It is nonetheless; clear that experience plays more role than family background as $46.4 \%$ of the correspondents have concurred; whereby only $3.6 \%$ of them have consented on the role of family background on Muslim individual worldview. This means the worldview of Muslim individuals emanate from the tawheed. The way they think and act are also in line with their tawheedic values.

According to Oxford English Dictionary worldview is "the contemplation of the world, view of life, the perception of the world, a particular philosophy of life and a concept of the world held by individuals" (Oxford English Dictionary) The Fontana Dictionary of Modern Thought describes worldview in this terms "Worldview refers to a general conception of the nature of the world, particularly as containing or implying a system of value-principles. Any total philosophical system may be so styled which derives practical consequences from its theoretical component". The same dictionary continues to 
define that, "Worldview refers to a general conception of the nature of the world, particularly as containing or implying a system of value-principles. Any total philosophical system may be so styled which derives practical consequences from its theoretical component". (Allan Bullock \& S. Trombley, 1999)

Anthonia Essien argues that "Worldview ... which is based on supernaturalism is shaped by many factors via: geographical location, historical background, economic situation, religious experiences and consciousness, political structure and social conditions". (Anthonia M. Essien, 2010). Jerry Solomon contends that worldview is a set of presuppositions which people hold about the basic makeup of their world. (Jerry Solomon, 2002) while, Clyde states worldview is the understanding, interpretation and responses which one derives from the world in which he lives in (Clyde 2005). Environmental case study on worldviews and values done by McGraw-Hill Companies, Inc, defines worldview as "set of basic beliefs, images, and values that make up a way of looking at and making sense of the world around us. It shapes how we interpret and interact with our environment and other people. Most worldviews are learned early in life and are not easily changed". (McGraw-Hill Companies, Inc, http://www.mhhe.com)

In general, the worldview of an individual is formed through revelation, intuition and stimuli. In other levels these values are represented by senses, thinking and action. Individual senses envelop seeing, hearing, testing and feeling, while thinking covers emoting, judging, perceiving, attending to, solving, controlling and deciding. Meanwhile, action refers to motivate, orient, and manipulate.

Islamic worldview, as a philosophy for life, is about comprehensiveness (shumuliyah) global, ('Alami,) and harmonizing enterprise of truth, haqul yaqin. It is an authentic article of life constructed upon tawheed. (Abdi O. Shuriye, 2006) In line with the above Faruqi contends, "The very business of life, the very matter of space-time the very process of history, are in turn declared by Islam to constitute religion ... Islam sees itself to all of space-time, and sits to determine all of history, all of creation, including all mankind" (Ismail Raji Al-Faruqi, 1995) For him tawheed is the worldview of a Muslim. "Tawheed is a general view of reality, of truth, of the world, of space and time, of human history and destiny" (Ismail Raji Al Faruqi, 1995) At the same time, Islamic worldview is the vertebrae of intellectual progress. Afif, on this argues that, "God has concluded His religions with Islam and provided Mohammed with a religion that benefits and accords with the intellectual progress of man, and suits all times and all places". (Afif A. Tabbarah, 1988) Ajijola reminds "The basis of any religion is faith. Faith is not merely a conviction of the truth of a given proposition but it is essentially the acceptance of a proposition as a basis for action. Without faith, a man is like a car without steering, drifting aimlessly upon the sea of doubt and confusion". (Alhaj A.D. Ajijola, 1982) In other words, Islamic worldview is the highest demonstration of Muslim individuals' philosophy and values.

A related aspect to the formation of worldview is life experience. It helps man to form his views on things around him and makes man more productive, professional and skillful. Indeed, experience can influence man's worldview but it may not be strong as tawheed. It is remarkable however, to observe in the survey that the respondents overlooked the role of family background to the formation of Muslim individual's worldview. Tawheed teaches that the family holds the ultimate responsibility of forming the worldview of the child. In actual fact, in Islamic value system the tawheedic stimulus is inborn. The Hadith of the Prophet reads: "No babe is born but upon Fitra (on tawheed), it is his parents who make him a Jew or a Christian or a Polytheist." (Bukhari and Muslim) In accord, the Islamic worldview is the original worldview of all mankind. Indeed, all Prophets from Adam to Muhammad sermonized only this worldview. In another Hadith, the Prophet reported that Allah said, in a Hadith al-Qudsi, "I created my servants in the right religion but devils made them go astray". (Bukhari and Muslim). Table 3.2 illustrates the output of the result based on frequency and percentage.

Table 3.2: Frequency and Percentage how I see things in life are based on my

\begin{tabular}{cccc}
\hline & Items & Frequency $(\mathrm{n})$ & Percentage (\%) \\
\hline Faith & 42 & 50.0 \\
& Experience & 39 & 46.4 \\
& Family background & 3 & 3.6 \\
\hline$(\mathrm{n}=84)$ & & &
\end{tabular}




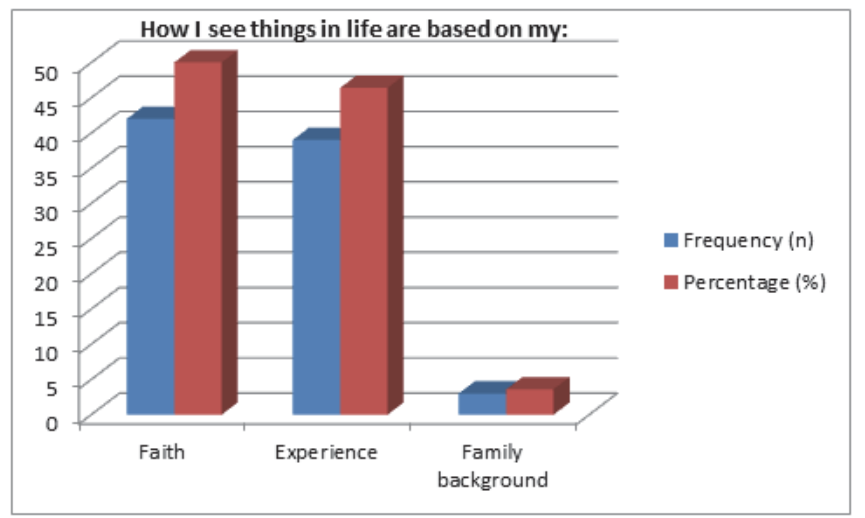

Ethics is the standards by which behaviours, attitudes and way life are evaluated for their rightness or wrongness. This part of the survey investigated the understanding of Muslim individuals on the role of ethics and its relation to faith. 36.9\% of the correspondents have disagreed on the item "My ethical principles are adequate for me to do the right things in Islam", while, $33.3 \%$ of them are unsure and only $29.8 \%$ have consented.

This result does not surprise me, in reality; it has been the contention of many intellectuals and professionals that ethics is not understood correctly on the part of modern Muslim individuals for various reasons related to history, religion in general and how Muslim individuals perceive tawheed. Hence, it was part of my academic endeavor, all this while, to consistently advocate that ethics should be taught as an independent course from early education in the Muslim world, an approach which is currently way deficient in the Muslim educational system. From the time of the golden age of Islam to this day, studies made on ethics are minimum compared to other Islamic fields. "Minute contributions have been established on Islamic ethics, weighed against, the number of volumes written on theology, Jurisprudence, Hadith and Tafir. Muslim Jurists were one of the contributors to the development of Islamic ethics, their contribution is mainly in the field of action ethics, and to them an action is correct if it is done with virtuous intent and in accordance with the pronouncement (tawheed)". (Abdi O. Shuriye, 2006)

Having said that, the contributions of few contemporary Muslim scholars to ethics is worth mentioning. Fazlur Rahma's Law and Ethics, Abd. Al- Haq al-Ansari's Islamic Ethics are two good sources on Islamic ethics. Ansari on the other hand has examines the fundamental ethical issues in the Qur'an as well as in the Sunnah, In his book Ethical Theories in Islam Majid Fakhry classifies Islamic ethics into philosophical ethics, spiritual ethics, theological ethics and religious ethics, Fakhry's work however is not inclusive, the Sufis contributions to ethics is one of the areas ignored by Fakhry. (Majid Fakhry, 1990) These scholars however, have not lay a hand on the question that why in the Muslim world the study of ethics is minute although we know this is due to the fact that mainstream Muslims see that ethics is part of religion and there is no necessity of developing it as an independent discipline in the hierarchy of Islamic sciences. (Abdi O. Shuriye, 2006)

However, ethics, Shari'ah and tawheed are the three core Muslim values and should be studied and developed as they complement one another to form the key apparatus which govern human action as a whole. Ethics is the manifestation of firm tawheed and at the same time, tawheed determines human values and standards of life for Muslim individuals. In accord Faruqi elucidates, "The humanism of tawheed alone is genuine. It alone respects man and creaturely, without either deification of vilification. It alone defines the worth of man in terms of his virtues, and begins its assessment of him with a positive mark for the innate endowment God has given all men in preparation for their noble task. It alone defines the virtues and ideals of human life in terms of the very contents of natural life, rather than denying them, thus making its humanism life-affirmative as well as moral" (Ismail Raji Al Faruqi, 1995) Majid Khadduri explains how sometimes ethics interacts with other values, "Ethical justice is often expressed in terms of certain values to justify human act that are out worldly in accord with conventional ethics but in reality are not necessary the expressions of the highest values." (Majid Khadduri, 1984) Table 3.3 demonstrates the frequency and percentage of the survey on: "ethical principles are adequate for me to do the right things in Islam". 
Table 3.3: Frequency and Percentage on ethical principles are adequate for me to do the right things in Islam.

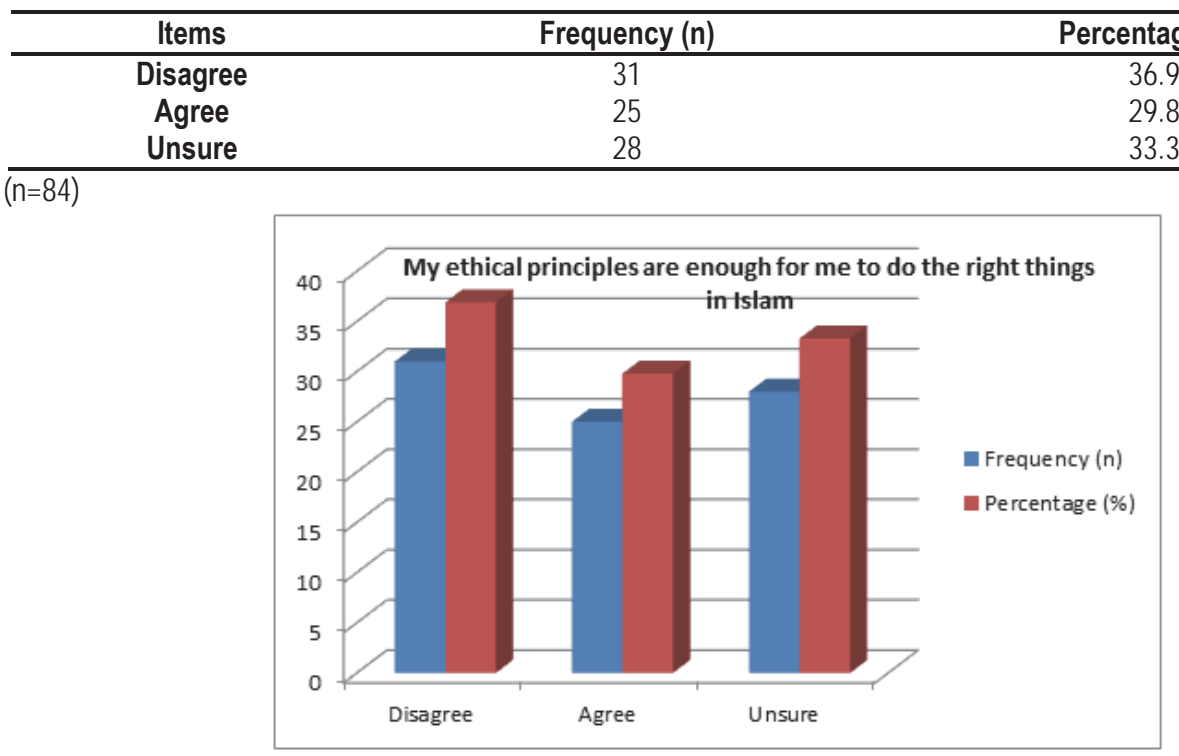

\section{Conclusion}

This paper is part of a larger ongoing research which investigates the influence of tawheed on worldview, the culture, the behavior, the attitude of Muslim individuals. Muslims today live in a society dominated by Western culture through their technological and scientific achievements and through their material and media supremacy. It is instrumental therefore to understand that modern Muslim individuals face huge challenges in maintaining their religiosity status and high tawheedic standards. It is also notable that the link between tawheed and modern life seem to become thinner. The daily life of a committed Muslim rests on tawheedic worldview; the essence of religion in Islam. Thus, it is crucial to remember that young Muslim individuals who have embraced the information age must be guided though the tawheedic worldviews. Technology and science are momentous in defining the understanding of the natural world but the purpose of tawheed is to provide mankind with a comprehensive depiction of the content and the behavior of the universe and man's role in it.

Muslim individual's life is governed by tawheed and how Muslims see things are mainly derived from it. The political world, the religious world and social world of a Muslim individual is understood within the context of tawheed. Religious consciousness is a tawheedic value. This research addressed tawheedic stimuli on Muslim life, on professionalism and on God consciousness (taqwa). It has further evaluated the sense of right and wrong in Islam, the influence of tawheed in avoiding sinful activities, and the role of faith on Muslim worldview. This part of the research studies the first two sections of a research based on a survey conducted on diverse Muslim individuals. A total of 84 participants were involved in the survey. The findings reveal that the Muslim individual has no idea the source of his predicaments in life in this modern world. However let me state that the ignorance of Muslim individuals about their religion, the cultural and political pluralism in the world we live in and the lack of parity between Islamic and Western cultures are the core of the contributing factors to the misconception on the role of tawheed on the part of many Muslims. We know that, in the actual life of a Muslim individual, values are distorted, knowledge and religious conviction are demarcated and tawheed and daily life are separated. Nonetheless, on survey they have shown that they indeed understand the role of tawheedic stimulus in their life.

\section{References}

Al-Qur'an al-Karim

Anthonia M. Essien 2010, the Sociological Implications of the Worldview of the Among People: An Advocacy for Paradigm Shift, Journal of Emerging Trends in Educational Research and Policy Studies (JETERAPS) 1 (1): 29-35

Clyde F. Autio, 2005, Worldview, in Petersburg, Kentucky Answers Magazine.

Jerry, Solomon 2002, culled from LEADERSHIP U: Probe Ministries, Richardson, Texas, United States of America.

McGraw-Hill Companies, Inc, http://www.mhhe.com

Ismail Raji Al Faruqi1995, Al Taw hid: Its Implications for Thought and Life, International Islamic Publishing House 
Asaf A.A. Fyzee 1981, a Modern Approach to Islam, Asia Publishing House and Oxford University Press

Afif A. Tabbarah 1988, the Spirit of Islam: Doctrine and Teachings, London.

Alhaj A.D. Ajijola 1982, the Essence of Faith in Islam, Islamic Publication Ltd

Syed Asad Gilani 1982, Islam, a Muslim, a Movement, Islamic publication NTD

Majid Khadduri 1984, The Islamic Conception of Justice, the John's Hopkins University Press

Majid Fakhry 1990, Ethical Theories in Islam, E.J. Brill, Leiden

Charles E Harris et al, 1995, Engineering Ethics, 1st Ed, England, Wadsworth Publishing Company

Abdi O. Shuriye 2006, Islamic Ethical Values on Bioengineering Practices: Issues in Genetic Engineering, IIUM, Kuala Lumpur. The Oxford English Dictionary

Allan Bullock, \& S. Trombley 1999, the New Fontana Dictionary of Modern Thought Harper Collins, London

Paul Chippendale 2001, On Values, Ethics, Morals \&Principles, A Values Inventory (AVI): www.minessence.net/html/aboutavi.htm Mohamed Bin Ismail al-Bukhari, 1987 Sahih al-Bukhari, Dar al-Qalam, Beirut

Muslim ibn Al-hajaj B. Muslim al-Qushayri An-Nisaburi, 1928 Sahih Muslim, Mustafa al-Babi, al-Halabi, Cairo 